\title{
Remineralization of Carious Dentin. II: In Vivo Microradiographic and Chemical Studies in Human Permanent Teeth Capped with Calcium Hydroxide
}

\author{
Carlos Alberto CONRADO \\ Department of Dentistry, State University of Maringá (UEM), Maringá, PR, Brazil
}

\begin{abstract}
The main aim of this in vivo study was to evaluate a possible remineralization of human carious dentin by means of chemical and microradiographic studies. Eighty-six samples of carious dentin were removed from 36 permanent teeth of 24 patients. These were divided into untreated (control) and chemically pure calcium hydroxide-capped (experimental) samples and analyzed at intervals varying from 10 to 120 days. They were classified according to depth of caries and degree of dentin softening and evaluated in relation to weight, phosphorus concentration, qualitative and quantitative microradiography and absolute values of total mineral content. One of two halves of each sample was selected for chemical studies and the other for total content of mineral salts. Experimental samples were examined with a light microscope and the results obtained showed a qualitative increase in radiopacity. Quantitatively, it was observed that, in the case of samples analyzed for phosphorus concentration, the average mean of differences in percentage increase after treatment was $9.6 \%$, while for the samples evaluated microradiographically for total mineral content, it was $22.29 \%$. In both cases, the differences were statistically significant.
\end{abstract}

Key Words: carious dentin, calcium hydroxide, carious dentin remineralization.

\section{INTRODUCTION}

Dental literature pertinent to carious dentin, in vitro and in vivo, was extensively reviewed by Conrado $(1,2)$. Several studies reported remineralization, rehardening and tertiary dentin formation after application of a variety of agents, including calcium hydroxide. Several reports clearly demonstrated its beneficial properties when applied over a layer of sound or carious dentin $(1,2)$.

In an in vitro study employing a methodology that utilized qualitative and quantitative microradiography, Conrado (1) demonstrated that in 39 freshly extracted human teeth (22 permanent and 17 deciduous) demineralized dentin could be remineralized when treated by chemically pure calcium hydroxide.

Calcium hydroxide was chosen for this study as the possible remineralizing capping agent. Three methods were chosen to evaluate this remineralization process: chemical analysis for phosphorus concentration, and qualitative and quantitative microradiography. These methods were chosen because they are considered suitable and accurate methods for studying not only mineralized dental tissues but also demineralized tissues $(3,4)$.

\section{MATERIAL AND METHODS}

Eighty-six samples of carious dentin were studied (43 experimental and 43 control), removed from 36 anterior and posterior permanent teeth of 24 patients (age range: $15-57$ years).

Thirty-one carious vital teeth were selected according to the following criteria: patients presenting a good state of general health, no clinical history of preoperative sensitivity, absence of any symptoms of pulp pathology, normal response to pulp testing, normal reactions to heat and cold, absence of mobility to finger pressure or sensitivity to percussion, lack of any radiographic evidence of periapical involvement, clini-

Correspondence: Prof. Dr. Carlos Alberto Conrado, Departamento de Odontologia, Universidade Estadual de Maringá, Clínica Odontológica da UEM, Av. Mandacaru 1550, Bloco Sø8, 87013-010 Maringá, PR, Brasil. Tel/Fax: +55-44-224-3633. e-mail: caconrado@wnet.com.br 
cal and radiographic evidence of relatively extensive intermediate or deep caries and sufficient clinical crown structure. Five carious pulpless teeth were also selected, adding to the criteria the adequate filling of root canals.

Seventy-six samples of carious dentin (38 experimental and 38 control) were removed from the 31 vital teeth and classified based on depth (intermediate and deep) and based on the resistance to the explorer (softened, semi-softened and harder). Thirty samples were classified as softened, 6 as semi-softened, two as harder, 32 as deep and 6 as intermediate. Ten samples of carious dentin were removed from the 5 pulpless teeth, 8 classified as softened deep and 2 as harder intermediate.

Time intervals ranged from 10 to 120 days with a mean of 45.2 days (vital teeth) and from 14 to 30 days with a mean of 23.4 days (pulpless teeth).

Conventional clinical procedures were carried out and standard cavity preparations were performed in each of the 36 permanent teeth. In each tooth, a more superficial and untreated layer of carious dentin was initially removed and a calcium hydroxide-capped layer removed after each time interval. Sharp spoon excavators were utilized for the removal of softened samples of carious dentin and special trepanation burs with a spiral form for the removal of semi-softened and harder samples. The exact localization of removal was recorded for every case in a specially designed chart.

A sharp cutting instrument was used to divide each softened or semi-softened sample and a carborundum disc each harder sample into two halves (left and right). Care was taken to identify both halves concerning their origin. Subsequently, the left half of each of the 86 samples was selected to be studied chemically and the right half of each of 62 samples, microradiographically. In order to obtain uniform samples, a special acrylic device for cutting carious dentin in a regular pattern was made, consisting essentially of an orifice in the center measuring $0.5 \mathrm{~mm}$ in depth and $3 \mathrm{~mm}$ in width, a screw and a blade. The movable screw allowed for horizontal cutting of specimens of widths varying from 0.5 to $3 \mathrm{~mm}$ and a standardization of specimens to $2 \mathrm{~mm}$. Thus, samples of carious dentin with $0.5 \mathrm{~mm}$ in depth and $2 \mathrm{~mm}$ in width were obtained.

The methodology utilized allowed comparisons between the thickness of layers of untreated and treated carious dentin from the same tooth area, thus diminishing the introduction of error, because it is well-known that the total mineral content of a carious process varies from tooth to tooth and within different areas of the same tooth.

The removed untreated control samples were analyzed both chemically and microradiographically. On the experimental samples, a freshly prepared mixture of chemically pure calcium hydroxide and distilled water was spread over the remaining underlying deeper layer of carious dentin. Zinc phosphate cement was used as the base material and silver amalgam or a resin as restorative materials.

After each time interval, the patients returned for clinical and radiographic evaluation and were examined according to the criteria previously described. Experimental procedures upon reopening of the cavities included removal of both restoration and base, calcium hydroxide and of the representative underlying capped layer of deep carious dentin.

The 86 experimental and control tooth-halves to be studied chemically were dried for $10 \mathrm{~h}$ at $105^{\circ} \mathrm{C}$ and weighed in a Mettler microbalance. The reason for this control procedure was to determine if differences in weighing between untreated and treated samples would influence the results. Phosphorus concentration was analyzed by means of a Beckman B spectrophotometer.

Sixty-two experimental and control right toothhalves were submitted to the same microradiographic procedures (4) as described by Conrado $(1,2)$. Differently from the in vitro experimental procedures (1), the longitudinal ground sections were of approximately $250 \mu \mathrm{m}$ in thickness, the final grinding and polishing resulting in a thickness varying from 74.5 to $122 \mu \mathrm{m}$. Following reopening and removal of the treated layer of carious dentin, the cavities were again restored with subsequent layers of calcium hydroxide, zinc phosphate cement and amalgam or resin.

\section{RESULTS}

Results demonstrated that a comparison between calcium hydroxide-treated and untreated samples of carious dentin as determined chemically and microradiographically showed an increase in mineral content of the treated samples interpreted as remineralization.

Analysis of variance revealed that there were no significant differences (5\% level) among time inter- 
vals, either regarding the chemical or the microradiographic evaluation.

Previous weighing showed no statistical differences between experimental and control samples. Chemical analysis demonstrated, in all cases except one, a marked increase in phosphorus concentration for the experimental samples from vital teeth when compared with control samples, the average means being 9.56\% (range $1.7-19.9 \%$ ) and $2.88 \%$ (range $0.1-8.4 \%$ ), respectively. This difference was statistically significant (Tukey test). The ten treated samples from pulpless teeth demonstrated an increase in phosphorus content whan compared with control samples.

In a majority of samples, qualitative microradiographic assessment showed a marked increase in the radiopacity of carious dentin of calcium hydroxidecapped samples from vital teeth.

For quantitative microradiography, thickness measurements and photometric procedures were performed for a total of 156 microscopic areas (78 from untreated and 78 from treated samples), in 3 areas of each sample. Applying Ericsson's (4) formula, in all cases except one, treated samples from vital teeth showed an increase in total mineral content $(22.29 \%$, range $2.95-40.24 \%$ ) when compared with untreated samples (7.51\%, range $0-30.52 \%)$. This difference was statistically significant (Tukey test).

Qualitative and quantitative microradiographs performed on the 5 treated samples of carious dentin from pulpless teeth showed a marked radiopacity and an increase in total mineral content, respectively.

\section{DISCUSSION}

In the present study, chemical and qualitative and quantitative microradiographic results showed an increase in phosphorus concentration, radiopacity and total mineral content in the great majority of samples of carious dentin treated with chemically pure calcium hydroxide, in vivo, as compared with uncapped control samples, thus indicating that a remineralization process must have occurred.

The differences associated with time intervals were statistically non-significant, confirming the results of an in vitro study by Conrado (1).

The remineralization effect induced by calcium hydroxide was evident even in those samples in which almost all of its total mineral content had suffered practically a complete demineralization, confirming previous results (1).

Sowden (5) reported that the thickness of recalcification depends upon the type of caries present at the preoperative examination, stating that softened caries presents a thicker white area of recalcification in a shorter period of time than harder caries. Mjør et al. (6) reported that the depth of the cavity preparation in which calcium hydroxide was applied did not seem to have a visible effect on the increase of mineralization. The findings of the present study did not establish any differences concerning either the depth of the cavity preparation or the type of caries studied.

One of the most revealing findings of this study was to verify upon reopening of the cavities that, if 30 untreated samples (out of 38) were removed initially with spoon excavators, its corresponding treated and immediately adjacent samples were removed with the special trepanation burs, a rehardening of the carious dentin was observed clinically.

The findings related to the chemical analysis showed a mean increase of $9.56 \%$, a figure quite close to the $8.35 \%$ reported by Eidelman et al. (3) also for samples capped with calcium hydroxide.

In the quantitative microradiographic analysis, an average increase in total mineral content of $22.29 \%$, observed in vivo, corresponds to some extent to the $32.70 \%$ verified in the in vitro experiments (1).

Results of the current study and those of the in vitro experiments conducted by Conrado (1), regarding pulpless teeth, indicate that remineralization can occur in the absence of pulp, but do not clarify the mechanism involved in such a process.

Gao et al. (9) commented upon the fact that, in accordance with the principles of modern operative dentistry to conserve tooth structure and to use therapeutic restorative materials, an understanding of carious lesions in dentin and the biological properties of dental materials is necessary, concluding that a delineation of the outer necrotic from the inner vital and remineralizable carious dentin allows for the preservation of tooth structure. Banerjee et al. (10) reported that in modern dentistry the primary aim when excavating carious dentin is to eradicate only the highly infected, irreversibly demineralized and denatured biomass in order to allow effective restoration of the cavity and to prevent disease progression.

To our understanding, the main clinical applica- 
tion of these experiments can be associated with the indirect pulp capping technique using calcium hydroxide as the agent, when the last portion of demineralized and largely uninfected $(7,8)$ and remineralizable dentin closer to the pulp is generally removed.

\section{RESUMO}

O principal objetivo deste estudo in vivo foi verificar uma possível remineralização da dentina cariada humana. Oitenta e seis amostras de dentina cariada foram estudadas, removidas de 36 dentes permanentes de 24 pacientes e divididas em nãotratadas (controles) e capeadas com hidróxido de cálcio quimicamente puro (experimentais), estudadas de acordo com períodos de observação entre 10 e 120 dias, classificadas levandose em conta profundidade e grau de amolecimento dentinário e avaliadas em relação a peso, concentração de fósforo, microradiografias qualitativas e quantitativas e valores absolutos de conteúdo mineral total. As amostras experimentais foram examinadas ao microscópio óptico e um aumento qualitativo em radiopacidade foi observado. Quantitativamente, foi mostrado que, no caso das amostras analisadas para concentração de fósforo, a média das diferenças em aumento de porcentagens após tratamento foi da ordem de $9.56 \%$, enquanto que para as amostras avaliadas microradiograficamente o aumento do conteúdo mineral total foi de $22.29 \%$. Em ambos os casos, as diferenças registradas foram estatisticamente significantes.

\section{ACKNOWLEDGEMENTS}

The author wishes to express his gratitude to Professors Hilding Nyborg of the University of Umea (Sweden) and Sven Gottmar Ericsson of the University of Stockholm (Sweden), both deceased, for their scientific and technical contribution to this work and to the Swedish Agency for International Development (SIDA), the Brazilian Ministry of Foreign Affairs and the Ribeirão Preto Dental School of the University of São Paulo for the grants awarded and financial support.

\section{REFERENCES}

1. Conrado CA. Remineralization of carious dentin. I: In vitro microradiographic study in human teeth capped with calcium hydroxide. Braz Dent J 2004:15:59-62.

2. Conrado CA. Verificação da remineralização da dentina cariada humana tratada com hidróxido de cálcio quimicamente puro por meio das técnicas de microradiografia qualitativa e quantitativa e da análise química de fósforo, in vivo. [Full Professor thesis]. Maringá, PR: Dental Department, State University of Maringá, Brazil, 1994. 146 p. Available at: <www.uem.br>

3. Eidelman E, Finn SB, Koulourides T. Remineralization of carious dentin treated with calcium hydroxide. J Dent Child 1965;32:218-225.

4. Ericsson SG. Quantitative microradiography of cementum and abrated dentine: a methodological and biological study. Acta Radiol (Suppl) 1965;246:1-137.

5. Sowden JR. A preliminary report on the recalcification of carious dentin. J Dent Child 1956;23:187-188.

6. Mjør IA, Finn SB, Quigley MB. The effect of calcium hydroxide and amalgam on non-carious vital dentine. Archs Oral Biol 1961;3:283-291.

7. Miyauchi H, Iwaku M, Fusayama T. Physiological recalcification of carious dentine. Bul Tokyo Med Dent Univ 1978;25:169-179.

8. Tatsumi T. Physiological remineralisation of artificially decalcified monkey dentine under adhesive composite resin restoration. J Jpn Stom Soc 1989;56:49-74.

9. Gao W, Smales RJ, Yip HK. Demineralisation and remineralisation of dentine caries, and the role of glass-ionomer cements. Int Dent J 2000;50:51-56.

10. Banerjee A, Watson TF, Kidd EA. Dentine caries: take it or leave it? Dent Update 2000;27:272-276.

Accepted September 29, 2003 